\title{
Ruthenacycles and Iridacycles as Catalysts for Asymmetric Transfer Hydrogenation and Racemisation
}

\author{
Thomas Jerphagnon - Robert Haak • Florian Berthiol • Arnaud J. A. Gayet • \\ Vincent Ritleng • Alexandre Holuigue • Nicolas Pannetier • Michel Pfeffer • \\ Adeline Voelklin · Laurent Lefort · Gerard Verzijl • Chiara Tarabiono • \\ Dick B. Janssen · Adriaan J. Minnaard • Ben L. Feringa · Johannes G. de Vries
}

Published online: 5 June 2010

(c) The Author(s) 2010. This article is published with open access at Springerlink.com

\begin{abstract}
Ruthenacycles, which are easily prepared in a single step by reaction between enantiopure aromatic amines and $\left[\mathrm{Ru}(\text { arene }) \mathrm{Cl}_{2}\right]_{2}$ in the presence of $\mathrm{NaOH}$ and $\mathrm{KPF}_{6}$, are very good asymmetric transfer hydrogenation catalysts. A range of aromatic ketones were reduced using isopropanol in good yields with ee's up to $98 \%$. Iridacycles, which are prepared in similar fashion from $\left[\mathrm{IrCp} * \mathrm{Cl}_{2}\right]_{2}$ are excellent catalysts for the racemisation of secondary alcohols and chlorohydrins at room temperature. This allowed the development of a new dynamic kinetic resolution of chlorohydrins to the enantiopure epoxides in up to $90 \%$ yield and $98 \%$ enantiomeric excess (ee) using a mutant of the enzyme Haloalcohol dehalogenase $\mathrm{C}$ and an iridacycle as racemisation catalyst.
\end{abstract}

T. Jerphagnon $\cdot$ R. Haak $\cdot$ F. Berthiol

A. J. A. Gayet · V. Ritleng - A. J. Minnaard .

B. L. Feringa · J. G. de Vries

Stratingh Institute of Chemistry, University of Groningen,

Nijenborgh 4, 9747 AG Groningen, NL, The Netherlands

V. Ritleng · A. Holuigue $\cdot$ A. Voelklin · L. Lefort · G. Verzijl · J. G. de Vries $(\square)$

DSM Innovative Synthesis bv, P. O. Box 18, 6160 MD Geleen, NL, The Netherlands

e-mail: Hans-JG.Vries-de@dsm.com

A. Holuigue $\cdot$ N. Pannetier $\cdot$ M. Pfeffer

Laboratoire de Synthèses Métallo-Induites, Institut de Chimie, CNRS, UMR 7177, Université de Strasbourg, 4, rue Blaise

Pascal, 67000 Strasbourg, France

C. Tarabiono - D. B. Janssen

Biomolecular Sciences and Biotechnology Institute, University

of Groningen, Nijenborgh 4, 9747 AG Groningen, NL,

The Netherlands
Keywords Asymmetric transfer hydrogenation . Ruthenium · Iridium · Metallacycle · Dynamic kinetic resolution - Chlorohydrin · Epoxide · Haloalcohol dehalogenase

\section{Introduction}

Asymmetric hydrogenation is arguably one of the most important methods for the catalytic synthesis of enantiopure compounds $[1,2]$. We have previously analysed that the relative low use of this technology in the production of pharmaceuticals, agrochemicals and flavour and fragrance products is due among others to the limited development time available and the high costs of the catalysts [3]. To counter this problem, we have developed a new class of low cost ligands for asymmetric hydrogenation that can be prepared in just two steps. Binol-based monodentate phosphoramidites can be synthesised in a mere 2 steps, making them not only highly cost-effective but also readily prepared in a short period of time even in $\mathrm{kg}$ amounts [4]. In addition, their easy preparation allows the parallel synthesis of 96 ligands simultaneously in high throughput equipment, enabling the synthesis and testing of these ligands within 2 days [5]. This approach has proven its usefulness in practice and has led to a ton-scale asymmetric hydrogenation process based on a rhodium phosphoramidite/triphenylphosphine catalyst [6].

We wanted to develop a similar approach to asymmetric transfer hydrogenation. This technology has the advantage that it can be easily applied on large scale without the need for high pressure equipment. The ligand types are even more diverse than those applied in asymmetric hydrogenation [7-9]. And although transfer hydrogenation catalysts are quite sensitive towards oxygen, they seem to be 
less sensitive to other impurities stemming from starting materials or solvents than the classical rhodium-, iridiumand ruthenium-based asymmetric hydrogenation catalysts. The first real breakthrough in this field stems from the work of Noyori and co-workers who developed catalysts that can be assembled in situ by reacting $\left[\mathrm{Ru}(\text { arene }) \mathrm{Cl}_{2}\right]_{2}$ with tosylated diamines, aminoalcohols or bis(aminophosphines) [10]. These catalysts led to high enantioselectivities in the asymmetric reduction of selected ketones and imines. Others have developed this field further and a great variety of ligands have been developed that include amino acid and peptide derivatives, aminoethers and aminothioethers [7-9]. The minimum requirement seems to be an amino group that carries at least one proton. These ligands are non-innocent as the proton on the amine participates in the transfer hydrogenation [11].

We were interested in developing a new class of asymmetric transfer hydrogenation catalysts based on a simple class of ligands that are modular and are easy to synthesise.

\section{Experimental Section}

Complexes 1-3 [12-14], 4a [15, 16], 4b [17], 6 [18], 7 [19], 8a-c [20] were prepared according to literature procedures.

\subsection{Typical Procedure for the Catalytic Transfer Hydrogenation}

The catalyst $(10 \mu \mathrm{mol})$ was dissolved in 2-propanol (10 mL) under argon, and acetophenone (120 mg, $1 \mathrm{mmol})$ was added, followed by $t \mathrm{BuOK}(5.6 \mathrm{mg}, 50 \mu \mathrm{mol})$. The reaction was periodically monitored by GC. Upon completion the solvent was evaporated, the crude product was dissolved in $\mathrm{Et}_{2} \mathrm{O}$ and filtered over silica gel using $\mathrm{Et}_{2} \mathrm{O}$ as eluent. The conversions and enantiomeric excess (ee) values were determined by GC using a chiral capillary column (Chiraldex $\beta$-PM, $50 \mathrm{~m} \times 0.25 \mathrm{~mm} \times 0.25 \mu \mathrm{m}$ ).

\subsection{Catalytic Racemisation of Alcohols}

In a flame-dried Schlenk flask under an atmosphere of nitrogen, $37.5 \mu \mathrm{mol}$ of catalyst and $41.2 \mu \mathrm{mol}$ of $\mathrm{KO} t \mathrm{Bu}$ were dissolved in $2.4 \mathrm{~mL}$ of freshly distilled toluene, after which $0.75 \mathrm{mmol}$ of chiral alcohol was added. The reaction was monitored by periodically taking $0.1 \mathrm{~mL}$ aliquots from the mixture, filtering them over silica gel (eluent: $\mathrm{Et}_{2} \mathrm{O}$ ) and analyzing the resulting samples by chiral GC (ChirasilDex CB column $(25 \mathrm{~m} \times 0.25 \mathrm{~mm} \times 0.25 \mu \mathrm{m})$, gas vector: helium, flow: $1 \mathrm{~mL} / \mathrm{min}$. Injector: $250{ }^{\circ} \mathrm{C}$. Program: $100{ }^{\circ} \mathrm{C}$ for $3 \mathrm{~min}, 120^{\circ} \mathrm{C}\left(15^{\circ} \mathrm{C} / \mathrm{min}\right)$ for $15 \mathrm{~min}, 140{ }^{\circ} \mathrm{C}$ $\left(15^{\circ} \mathrm{C} / \mathrm{min}\right)$ for $15 \mathrm{~min}, 100{ }^{\circ} \mathrm{C}\left(15^{\circ} \mathrm{C} / \mathrm{min}\right)$ or chiral HPLC (OD-H column, hexane/isopropanol (95/5)).

\subsection{General Method for the DKR of $\beta$-Haloalcohols}

A $50 \mathrm{~mL}$ two-necked flask was charged with $10 \mathrm{~mL}$ of 4-(2-hydroxyethyl)-1-piperazineethanesulfonic acid (HEPES) buffer $(50 \mathrm{mM}, \mathrm{pH} 8.0)$, a solution of $200 \mu \mathrm{mol}$ of substrate in $0.5 \mathrm{~mL}$ of distilled DMSO, $35 \mathrm{mg}$ of bovine serum albumin (BSA), and about $6 \mathrm{U}^{1}$ of haloalcohol dehalogenase $\mathrm{C}(\mathrm{C} 153 \mathrm{~S}, \mathrm{~W} 249 \mathrm{~F}){ }^{2}$ Then, a solution of $\mathbf{8 b}$ (6.3 mg, $10 \mu \mathrm{mol}, 5 \mathrm{~mol} \%)$ and $\mathrm{KO} t \mathrm{Bu}(1.2 \mathrm{mg}, 11 \mu \mathrm{mol})$ in $3 \mathrm{~mL}$ of freshly distilled toluene was added to the solution over $6 \mathrm{~h}$ using a syringe pump. To analyze the composition of the reaction mixture, $0.1 \mathrm{~mL}$ samples were taken from the organic layer, filtered over silica (eluent: $\mathrm{Et}_{2} \mathrm{O}$ ), concentrated in vacuo, redissolved in heptane/IPA and analyzed by chiral HPLC or GC. In those cases where the products were isolated, the reaction mixture was extracted with EtOAc, dried over $\mathrm{MgSO}_{4}$, filtered, and the filtrate concentrated under reduced pressure. The resulting crude products were purified by column chromatography over silica gel, using mixtures of heptane and EtOAc as eluent.

\subsection{Ruthenacycles as Transfer Hydrogenation Catalysts}

As part of a $\mathrm{CH}$-activation project, we were investigating ruthenacycle 1a, which is capable of inserting olefins into the metal-carbon bond $[22,23] .{ }^{3}$ This ruthenacycle, which is surprisingly stable is very easily synthesised from [Ru(arene) $\left.\mathrm{Cl}_{2}\right]_{2}$ according to Scheme 1 [19]. A simple flash column over alumina gave essentially pure material. These ruthenacycles are chiral at ruthenium, however, they are not configurationally stable. We assume that easy racemisation occurs by a dissociation/association of the acetonitrile ligand. The diastereomeric ratio $(d r)$ of the ruthenacycle depends of course on the ligands. In the case of 1a the $d r$ was 74:26 [19].

Use of ruthenacycle $1 \mathbf{a}$ as catalyst $(\mathrm{S}: \mathrm{C}=100)$ in the asymmetric transfer hydrogenation of acetophenone, using iso-propanol as reductant and solvent and $\mathrm{KO} t \mathrm{Bu}$ as activator led to a $48 \%$ yield of 1-phenylethanol after $2 \mathrm{~h}$ with a product ee of $10 \%$ (Table 1, entry 1) [25].

As this catalyst possesses no proton on the amino ligand, we must assume a mechanism different than the one

\footnotetext{
${ }^{1}$ One $\mathrm{U}$ is defined as that amount of the enzyme that catalyzes the conversion of $1 \mu \mathrm{mol}$ of substrate per minute.

${ }^{2}$ Enzyme activity was routinely measured using a spectrophotometric method described in [21].

${ }^{3}$ For a review on ruthenacyles see [24].
} 
Scheme 1 Synthesis of ruthenacycles

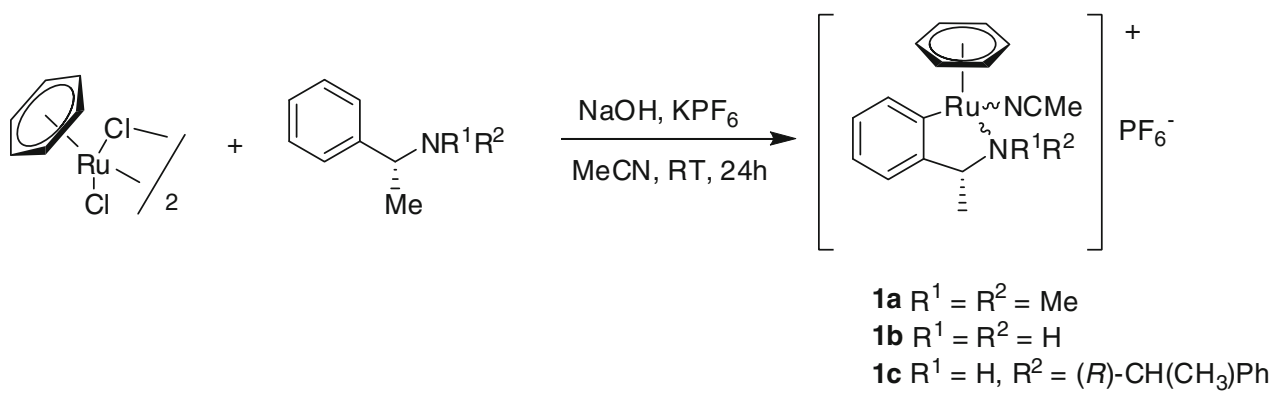

Table 1 Asymmetric transfer hydrogenation using ruthenacycle catalysts $^{\mathrm{a}}$

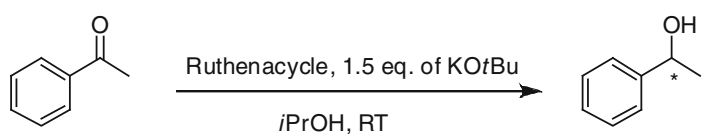

\begin{tabular}{lllll}
\hline Entry & Catalyst & Time $(\mathrm{min})$ & Yield & ee $(\%)$ \\
\hline $1^{\mathrm{b}}$ & $\mathbf{1 a}$ & 120 & 48 & $10(S)$ \\
$2^{\mathrm{b}}$ & $\mathbf{1 b}$ & 60 & 97 & $38(S)$ \\
3 & $\mathbf{1 c}$ & 30 & 96 & $76(S)$ \\
4 & $\mathbf{1 c}\left(0^{\circ} \mathrm{C}\right)$ & 120 & 95 & $85(S)$ \\
5 & $\mathbf{2}$ & 270 & 49 & $89(S)$ \\
6 & $\mathbf{3}$ & 10 & 90 & $57(S)$ \\
\hline${ }^{2}$ Conditions: ketone & $(1 \mathrm{mmol})$ & in & $10 \mathrm{ml}$ & $i \operatorname{PrOH}$, \\
S:C:KOtBu $=100: 1: 1.5, \mathrm{RT}$ & & & \\
b $\mathrm{S}: \mathrm{C}: \mathrm{KO} t \mathrm{Bu}=100: 1: 5$ & & &
\end{tabular}

proposed by Noyori. Encouraged by this first result we decided to synthesise the ruthenacycle $\mathbf{1 b}$, which contains an $\mathrm{NH}_{2}$-group. Indeed, not only was the transfer hydrogenation rate much higher, also the ee of the product alcohol improved to $38 \%$ (Entry 2). As we wanted to screen a broad range of chiral aromatic primary and secondary amines we decided to use a High Throughput Experimentation (HTE) approach. Indeed, we were able to automate both the synthesis of the ruthenacycles as well as their screening in the transfer hydrogenation using a Lizzy liquid dispensing robot that is positioned in a glovebox [25]. After completion of the ruthenacycle synthesis the solvent acetonitrile, which is an inhibitor for the transfer hydrogenation was removed by blowing nitrogen through the vials; iso-propanol was added, followed by the substrate acetophenone and finally a solution of $\mathrm{KO} t \mathrm{Bu}$ ( 1.5 equiv to $\mathrm{Ru}$ ) to activate the catalyst. In this way we screened a small library of nine amines, which led to the finding that in fact secondary aromatic amines are superior ligands. Three catalysts that gave very good results were the ruthenacycles $\mathbf{1 c}, \mathbf{2}$ and $\mathbf{3}$ (Fig. 1). These were resynthesised and the good results were confirmed with the purified compounds. Use of catalyst 1c led to formation of the alcohol in virtually quantitative yield in just half an hour yielding the product

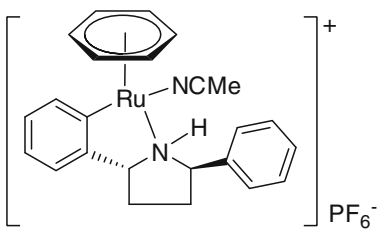

2

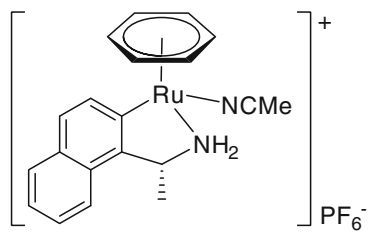

3
Fig. 1 Ruthenacycles

in $76 \%$ ee (Entry 3). Lowering the temperature to $0{ }^{\circ} \mathrm{C}$ improved the ee further to $85 \%$, although the rate slowed down somewhat (Entry 4). A very good ee of $89 \%$ was also obtained with catalyst $\mathbf{2}$ based on 2,5-diphenylpyrrolidine (Entry 5). Catalyst 3 based on 1-(2-naphthyl)-ethylamine turned out to be very fast: even after $10 \mathrm{~min}$ the alcohol was obtained in $90 \%$ yield $\left(\mathrm{TOF}=540 \mathrm{~h}^{-1}\right)$ although the ee was only a mediocre $57 \%$ (Entry 6). We next screened a range of aromatic substrates using the best two catalysts $\mathbf{1 c}$ and $\mathbf{2}$ which led to some interesting findings (Table 2).

It is clear from the results in Table 2 (Entry 2) that aromatic ketones containing electron withdrawing groups such as $\mathbf{B}$ are hydrogenated very fast (TOF $>500 \mathrm{~h}^{-1}$ ), but with low enantioselectivity. Another interesting finding is the fact that branching in the alpha position on the aliphatic side of the ketone leads to much improved enantioselectivities, particularly with catalyst 1c (Entries 3-5). Tetralone was reduced with excellent enantioselectivity by catalyst 2 (Entry 6). Both catalysts were able to reduce 4-acetyl-styrene without reducing the $\mathrm{C}-\mathrm{C}$ double bond as well as 2-acetylfuran with very good enantioselectivity (Entries 7, 8).

\subsection{Ruthenacycles and Iridacycles as Alcohol Racemisation Catalysts}

In all of the above reductions it is observed that the enantioselectivity of the products decreases somewhat over time during the reaction. This is caused by the reversibility of the transfer hydrogenation. The enantiomer that is formed in excess is also the one that is more easily oxidized in the Oppenauer oxidation. Although this is a nuisance in the asymmetric transfer hydrogenation, this racemising 
Table 2 Scope of asymmetric transfer hydrogenation using Ruthenacycles $\mathbf{1 c}$ and $\mathbf{2}^{\mathrm{a}}$<smiles>CC(=O)c1ccccc1</smiles>

A

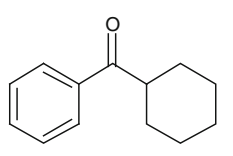

$E$

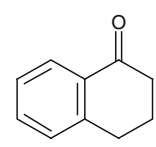

$\mathbf{F}$

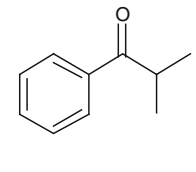

C

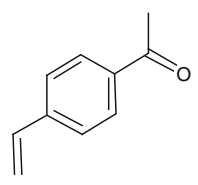

G

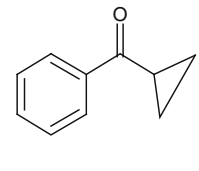

D

H

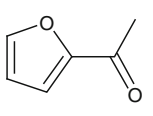

\begin{tabular}{|c|c|c|c|c|c|}
\hline \multirow[t]{2}{*}{ Entry } & \multirow[t]{2}{*}{ Substrate } & \multicolumn{2}{|l|}{ 1c } & \multicolumn{2}{|l|}{2} \\
\hline & & Yield (\%) & ee $(\%)$ & Yield (\%) & ee $(\%)$ \\
\hline 1 & $\mathbf{A}$ & $95^{\mathrm{b}}$ & 85 & 92 & 89 \\
\hline 2 & B & $99^{\mathrm{c}}$ & 29 & $96^{\mathrm{b}}$ & 35 \\
\hline 3 & $\mathbf{C}$ & 97 & 98 & 95 & 48 \\
\hline 4 & D & $32^{\mathrm{d}}$ & 89 & $44^{\mathrm{d}}$ & 45 \\
\hline 5 & $\mathbf{E}$ & 97 & 98 & 74 & 48 \\
\hline 6 & $\mathbf{F}$ & - & - & 59 & 94 \\
\hline 7 & $\mathbf{G}$ & 88 & 87 & 91 & 86 \\
\hline 8 & H & 95 & 86 & 82 & 87 \\
\hline
\end{tabular}

Bold values indicate the best ee values

${ }^{\text {a }}$ Conditions: ketone $\left(10^{-1} \mathrm{M}\right)$ in $10 \mathrm{~mL}$ of $i \mathrm{PrOH}$; $\mathrm{S}: \mathrm{C}: \mathrm{tBuOK}=$ 100:1:5, RT, $1 \mathrm{~h}$

b $0{ }^{\circ} \mathrm{C}$

c $10 \mathrm{~min}$

d $4 \mathrm{~h}$

capacity can actually be put to good use. The most wellknown use is in the dynamic kinetic resolution (DKR) of alcohols as developed by Williams [26] and Bäckvall [27]. In this reaction only one of the enantiomers of a racemic alcohol is acylated, catalysed by a lipase enzyme (Scheme 2). The other enantiomer that remains unreacted is continuously racemised, thus leading to a $100 \%$ yield of the acylated alcohol. Bäckvall and co-workers initially used the Shvo catalyst 4a (Fig. 2) for the racemisation reaction, but later developed monomeric equivalents such

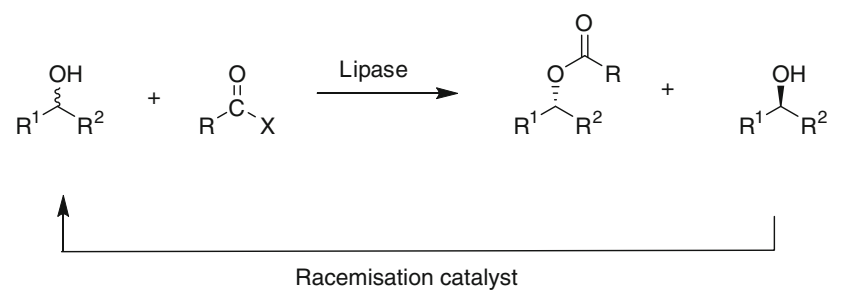

Scheme 2 Dynamic kinetic resolution of alcohols as $\mathbf{5}$ that were even more active as racemisation catalyst [28]. This DKR has been further developed by Verzijl and co-workers leading to its application in a large-scale process at DSM [29]. Bäckvall and co-workers have shown that it is also possible to subject chlorohydrins to the same conditions to obtain enantiopure acylated chlorohydrins (Scheme 3) [30]. These compounds can then be treated with base to obtain the enantiopure epoxides. We were interested to develop a new DKR of chlorohydrins directly to the enantiopure epoxides by using a haloalcohol dehalogenase instead of a lipase.

The use of haloalcohol dehalogenase for the kinetic resolution of halohydrins has been largely developed by Janssen and co-workers (Scheme 4) [31-34]. The enzyme also catalyses the reverse reaction between epoxides and small anionic nucleophiles such as azide, cyanide or nitrite.

Thus, if a catalyst can be found that can racemise chlorohydrins a direct DKR becomes possible. However, unlike lipases, haloalcohol dehalogenases need to be dissolved in water for activity. In addition, these enzymes are not heat stable. This puts some extra restrictions on the racemisation catalyst: it should be able to function in the presence of water at moderate temperatures. Thus we screened a number of known catalysts in the racemisation of both phenylethanol (a) and 2-chloro-1-phenylethanol (b) (Table 3). Both catalysts $\mathbf{4 a}$ and $\mathbf{4 b}$ that were developed by Shvo are capable of racemising $\mathbf{a}$ as well as $\mathbf{b}$, however, elevated temperatures are needed resulting in formation of ketone as side product. It is clear that this high temperature is not compatible with the enzyme. Much better results were obtained with catalyst $\mathbf{6}$ developed by Park and co-workers which was capable of full racemisation of both alcohols within half an hour at room temperature [19]. Unfortunately, the catalyst failed completely under aqueous conditions. Ruthenacycle $\mathbf{7}$ as expected was an excellent racemisation catalyst for a at room temperature and even functioned under aqueous conditions, albeit somewhat slower. However, the catalyst was incapable of racemising chlorohydrin $\mathbf{b}$. We surmised that this could be due to catalyst inhibition caused by the chloroketone, which is a strong alkylating agent. Indeed upon addition of phenacyl chloride to the racemisation reaction of a, catalysed by $\mathbf{7}$, the reaction immediately stalled.

Encouraged by the high reactivity of the ruthenacycle 7 on a, we decided to test the iridacycles 8a-c. These compounds are made in similar fashion as the ruthenacycles starting from $\left[\operatorname{Ir}\left(\mathrm{Cp}^{*}\right) \mathrm{Cl}_{2}\right]_{2}$, by reaction with the appropriate amine, $\mathrm{NaOH}$ and $\mathrm{KPF}_{6}$ in $\mathrm{MeCN}$. They were isolated in pure form in good yields after a flash column over alumina. The catalysts are activated by treatment with $\mathrm{KO} t \mathrm{Bu}$. We found a larger difference in reactivity dependent on the substitution pattern on the nitrogen. In this case, the catalyst based on the primary amine $\mathbf{8 a}$ is not better 
Fig. 2 Racemisation catalysts
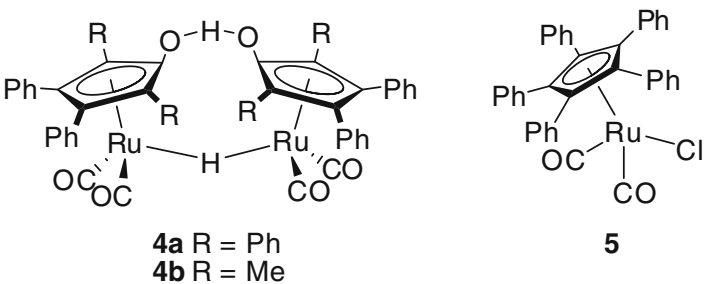

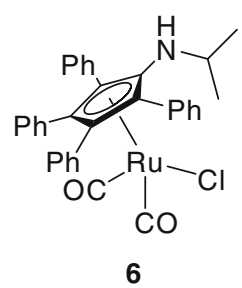
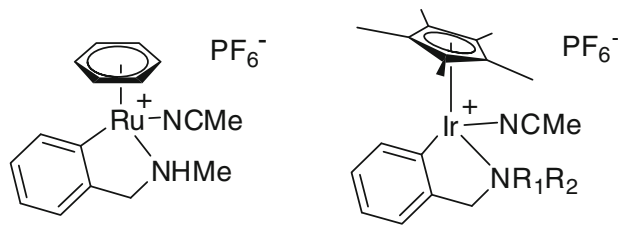

$$
\begin{aligned}
& \text { 8a R1 }=R 2=H \\
& \text { 8b R1 }=\text { Me, R2 }=H
\end{aligned}
$$

7

Scheme 3 DKR approach to enantiopure epoxides from Bäckvall [29]

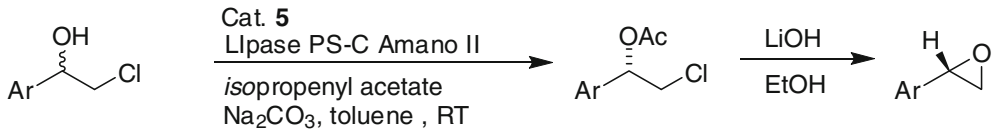

$$
\begin{aligned}
& \overbrace{\mathrm{R}}^{\mathrm{OH}} \mathrm{x} \rightleftharpoons \mathrm{HheC}_{\mathrm{H}}^{\mathrm{O}}+\overbrace{\mathrm{R}}^{\stackrel{\mathrm{OH}}{\dot{\mathrm{H}}} \mathrm{X}}+\mathrm{HX}^{\mathrm{H}} \\
& \mathrm{X}=\mathrm{Br}, \mathrm{Cl}
\end{aligned}
$$

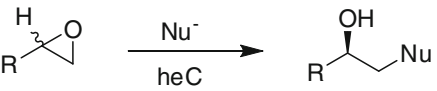

$$
\begin{aligned}
& \mathrm{Nu}^{-}=\mathrm{N}_{3}^{-}, \mathrm{NO}_{2}^{-}, \mathrm{CN}^{-}
\end{aligned}
$$

Scheme 4 Use of haloalcohol dehalogenase C (HheC) as catalyst for the kinetic resolution of chlorohydrins or epoxides

Table 3 Racemisation of alcohols

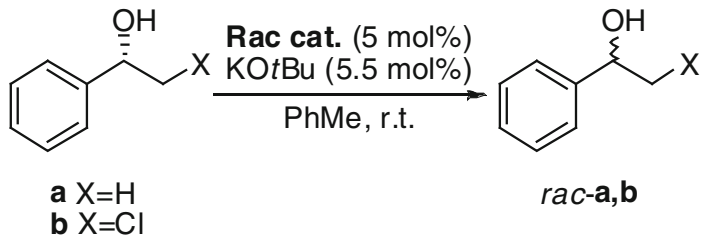

\begin{tabular}{llllll}
\hline Entry & Catalyst & Time $(\mathrm{h})$ & $\mathrm{T}\left({ }^{\circ} \mathrm{C}\right)$ & 1-Phenylethanol $(\mathbf{a})$ ee $(\%)$ & 3-Chloro-1-phenyl- ethanol $(\mathbf{b})$ ee $(\%)$ \\
\hline 1 & $\mathbf{4 a}$ & 29 & 80 & $0(20 \%$ ketone $)$ & $8(9 \%$ ketone $)$ \\
2 & $\mathbf{4 b}$ & 24 & 80 & $44(30 \%$ ketone $)$ & $24(20 \%$ ketone $)$ \\
3 & $\mathbf{6}$ & 0.5 & r.t. & 0 & 4 \\
4 & $\mathbf{6}(\mathrm{Tol} / \mathrm{aq})$ & 10 & r.t. & 100 & 100 \\
5 & $\mathbf{7}$ & 7 & r.t. & 8 & 100 \\
6 & $\mathbf{7}(\mathrm{Tol} / \mathrm{aq})$ & 46 & r.t. & 8 & 100 \\
\hline
\end{tabular}


Fig. 3 Racemisation of $(S)-1-$ phenylethanol (a) and (S)-2chloro-1-phenylethanol (b) using iridacycles 8a-c (Reaction conditions: $0.20 \mathrm{mmol}$ of enantiopure substrate in $3 \mathrm{ml}$ of toluene, $4 \mathrm{~mol} \%$ of $\mathbf{8}, 5 \mathrm{~mol} \%$ of $\mathrm{KO} t \mathrm{Bu}, \mathrm{RT})$

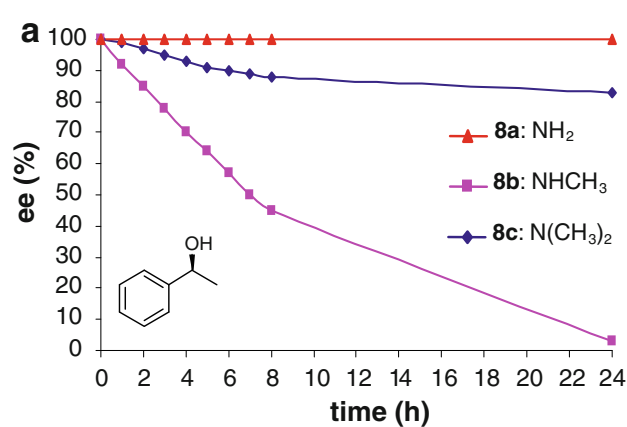

\subsection{Dynamic Kinetic Resolution of Chlorohydrins}

Having solved the problem of a finding a suitable racemisation catalyst we started working on the dynamic kinetic resolution of the chlorohydrins. First experiments were not encouraging as the enzyme and the racemisation catalyst somehow seemed to inhibit each other. We were able to solve these problems in the following way. The substrate chlorohydrin was dissolved in a little bit of DMSO and added to the enzyme solution in HEPES buffer. To protect the enzyme, bovine serum albumin (BSA) was added. The racemisation catalyst $\mathbf{8 b}$ was slowly added over a $6 \mathrm{~h}$ period as a toluene solution, thus mitigating its rapid deactivation. In view of its high activity this was sufficient to obtain a good conversion. Indeed after $16 \mathrm{~h}$ a $90 \%$ conversion of b was observed and the remaining $5 \%$ of chlorohydrin had an ee of $75 \%$ showing that the racemisation catalyst was still active (Scheme 5) [35]. The product epoxide was obtained in $98 \%$ ee. The protective action of BSA presumably is based on its preferential location at the aqueous/organic interphase, thus effectively preventing contact between the two catalysts. Having thus established the conditions for the successful DKR of aromatic chlorohydrins we next tested the scope of this reaction (Table 4).

In general, aromatic chlorohydrins with substituents in the 3- and 4-positions were efficiently converted (Table 4, entries 1-3, 5-7). However, ortho-substituents are not well tolerated by the enzyme and in this case the reaction is rather slow (Entry 4).

The attempted DKR of chloromethyl cyclohexyl ketone only proceeded in $50 \%$ yield and indeed the remaining chlorohydrin had a high ee, suggesting that this particular
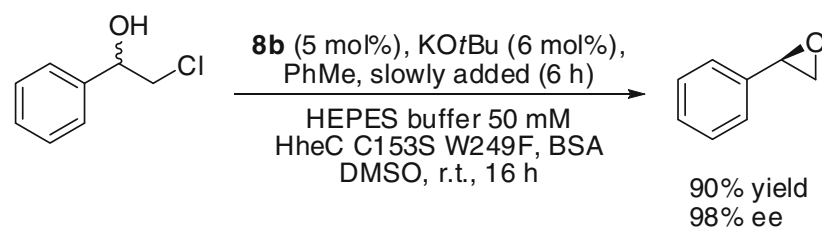

Scheme 5 DKR of aromatic chlorohydrins
Table 4 DKR of aromatic chlorohydrins

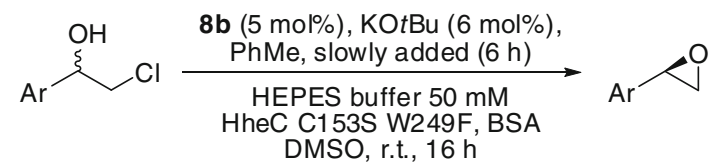

\begin{tabular}{llll}
\hline Entry & $\mathrm{Ar}$ & Conv. (\%) & ee (\%) \\
\hline 1 & $\mathrm{C}_{6} \mathrm{H}_{5}$ & 90 & 98 \\
2 & $4-\mathrm{NO}_{2}-\mathrm{C}_{6} \mathrm{H}_{4}$ & 80 & 95 \\
3 & $3-\mathrm{NO}_{2}-\mathrm{C}_{6} \mathrm{H}_{4}$ & 75 & 97 \\
4 & $2-\mathrm{NO}_{2}-\mathrm{C}_{6} \mathrm{H}_{4}$ & 28 & 91 \\
5 & $4-\mathrm{CN}-\mathrm{C}_{6} \mathrm{H}_{4}$ & 67 & 95 \\
6 & $3-\mathrm{MeO}_{-} \mathrm{C}_{6} \mathrm{H}_{4}$ & 64 & 85 \\
7 & $4-\mathrm{CF}_{3}-\mathrm{C}_{6} \mathrm{H}_{4}$ & 58 & 98 \\
\hline
\end{tabular}

substrate is not efficiently racemised. However, less-hindered aliphatic alcohols such as 2-butanol and 2-hexanol could be efficiently racemised using catalyst $\mathbf{8 b}$.

\section{Conclusions}

In conclusion, we have shown that ruthenacycles, prepared in a single step from enantiopure aromatic amines by reaction with $\left[\mathrm{Ru} \text { (benzene) } \mathrm{Cl}_{2}\right]_{2}$ in the presence of $\mathrm{NaOH}$ and $\mathrm{KPF}_{6}$, are efficient asymmetric transfer hydrogenation catalysts. Ruthenacycles are also efficient racemisation catalysts for secondary alcohols at room temperature, although they could not racemise chlorohydrins as the corresponding chloroketone turned out to be a catalyst inhibitor. Iridacycles prepared in a similar manner from the aromatic amines and $\left[\mathrm{IrCp} * \mathrm{Cl}_{2}\right]_{2}$ were not inhibited and also functioned well in an aqueous environment. This allowed the dynamic kinetic resolution of aromatic chlorohydrins to the enantiopure epoxides in very good yields by using a combination of iridacycle $\mathbf{8 b}$ and Haloalcohol dehalogenase $\mathrm{C}$, which had been mutated in two positions.

Acknowledgements Financial support from the Netherlands Organisation for Scientific Research (NWO-CW/STW), the Dutch 
Ministry of Economic Affairs, Royal DSM N.V., and N.V. Organon, administered through the IBOS program is gratefully acknowledged.

Open Access This article is distributed under the terms of the Creative Commons Attribution Noncommercial License which permits any noncommercial use, distribution, and reproduction in any medium, provided the original author(s) and source are credited.

\section{References}

1. de Vries JG, Elsevier CJ (eds) (2007) The handbook of homogenous hydrogenation, vols $1-3$. Wiley- $\mathrm{VCH}$, Weinheim

2. Special Issue on hydrogenation and transfer hydrogenation (2007) Acc Chem Res 12:1237-1419

3. de Vries JG, de Vries AHM (2003) Eur J Org Chem 799

4. Minnaard AJ, Feringa BL, Lefort L, de Vries JG (2007) Acc Chem Res 40:1267

5. Lefort L, Boogers JAF, de Vries AHM, de Vries JG (2004) Org Lett 6:1733

6. Boogers JAF, Felfer U, Kotthaus M, Lefort L, Steinbauer G, de Vries AHM, de Vries JG (2007) Org Proc Res Dev 11:585

7. Ikariya T, Blacker AJ (2007) Acc Chem Res 40:1300

8. Blacker AJ (2007) In: de Vries JG, Elsevier CJ (eds) The handbook of homogenous hydrogenation. Wiley $\mathrm{VCH}$, Weinheim, $\mathrm{p}$ 1215

9. Gladiali S, Alberico E (2006) Chem Soc Rev 35:226

10. Noyori R, Hashiguchi S (1997) Acc Chem Res 30:97

11. Haack K-J, Hashiguchi S, Fujii A, Ikariya T, Noyori R (1997) Angew Chem Int Ed Engl 36:285

12. Sortais JB, Pannetier N, Holuigue A, Barloy L, Sirlin C, Pfeffer M, Kyritsakas N (2007) Organometallics 26:1856

13. Sortais JB, Pannetier N, Clement N, Barloy L, Sirlin C, Pfeffer M, Kyritsakas N (2007) Organometallics 26:1868-1874

14. Pannetier N, Sortais J-B, Dieng PS, Barloy L, Sirlin C, Pfeffer M (2008) Organometallics 27:5852

15. Blum Y, Shvo Y (1984) Isr J Chem 24:144
16. Blum Y, Czarkle D, Rahamim Y, Shvo Y (1985) Organometallics 4:1459

17. Shvo Y, Czarkie D, Rahamim Y (1986) J Am Chem Soc 108:7400

18. Choi JH, Kim YH, Nam SH, Shin ST, Kim M-J, Park J (2002) Angew Chem Int Ed 41:2373

19. Fernandez S, Pfeffer M, Ritleng V, Sirlin C (1999) Organometallics 18:2390

20. Jerphagnon T, Gayet AJA, Berthiol F, Ritleng V, Mršić N, Meetsma A, Pfeffer M, Minnaard AJ, Feringa BL, de Vries JG (2009) Chem Eur J 15:12780

21. Lutje Spelberg JH, Tang L, Van Gelder M, Kellogg RM, Janssen DB (2002) Tetrahedron Asymm 13:1083

22. Ritleng V, Pfeffer M, Sirlin C (2003) Organometallics 22:347

23. Ritleng V, Sutter JP, Pfeffer M, Sirlin C (2000) Chem Commun 129

24. Djukic J-P, Sortais J-B, Barloy L, Pfeffer M (2009) Eur J Inorg Chem 817

25. Sortais J-B, Ritleng V, Voelklin A, Holuigue A, Smail H, Barloy L, Sirlin C, Verzijl GKM, Boogers JAF, de Vries AHM, de Vries JG, Pfeffer M (2005) Org Lett 7:1247

26. Dinh PM, Howarth JA, Hudnott AR, Williams JMJ, Harris H (1996) Tetrahedron Lett 37:7623

27. Larsson ALE, Persson BA, Bäckvall J-E (1997) Angew Chem Int Ed Engl 36:1211

28. Martín-Matute B, Edin M, Bogár K, Kaynak FB, Bäckvall J-E (2005) J Am Chem Soc 127:8817

29. Verzijl GKM, de Vries JG, Broxterman QB (2005) Tetrahedron Asymm 16:1603

30. Träff A, Bogár K, Warner M, Bäckvall J-E (2008) Org Lett 10:4807

31. Janssen DB (2007) Adv Appl Microbiol 61:23

32. de Jong RM, Dijkstra BW (2003) Curr Opin Struct Biol 13:722

33. de Vries EJ, Janssen DB (2003) Curr Opin Biotechnol 14:414

34. Fetzner S, Lingens F (1994) Microbiol Rev 59:641

35. Haak RM, Berthiol F, Jerphagnon T, Gayet AJA, Tarabiono C, Postema CP, Ritleng V, Pfeffer M, Janssen DB, Minnaard AJ, Feringa BL, de Vries JG (2008) J Am Chem Soc 130:13508 